\title{
BRAZILIAN VERSION (ACSI-28BR) OF ATHLETIC COPING SKILLS INVENTORY-28
}

\author{
VERSÃO BRASILEIRA (ACSI-28BR) DO ATHLETIC COPING SKILLS INVENTORY-28 \\ VERSIÓN BRASILEÑA (ACSI-28BR) DEL ATHLETIC COPING SKILLS INVENTORY-28
}

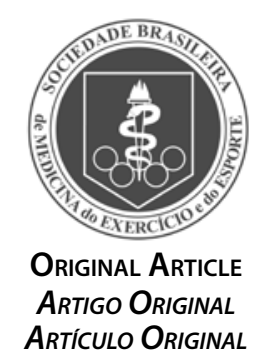

Renato Miranda'
(Physical Education Professional)
Danilo Reis Coimbra ${ }^{2}$
(Physical Education Professional)
Maurício Gattás Bara Filho
(Physical Education Professional)
Márcio Vidigal Miranda Júnior'
(Physical Education Professional)
Alexandro Andrade ${ }^{2}$
(Physical Education Professional)

1. Universidade Federal de Juiz de Fora (UFJF), Faculdade de Educação Física e Desportos, Department of Physical Education, Juiz de Fora, MG, Brazil.

2. Universidade do Estado de Santa Catarina (UDESC), Centro de Ciências da Saúde e do Esporte (CEFID), Department of Physical Education, Laboratório de Psicologia do Esporte e do Exercício (LAPE), Florianópolis, SC, Brazil.

\section{Correspondence:}

Danilo Reis Coimbra

Universidade do Estado de Santa

Catarina (UDESC), Centro de

Ciências da Saúde e do Esporte.

Rua Pascoal Simone, 358, Coqueiros, Florianópolis, SC, Brazil. 88080-350. daniloreiscoimbra@yahoo.com.br

\begin{abstract}
Introduction: Coping is defined as a process based on motor, behavioral, and cognitive effort to deal with the psychophysical demands that exceed an individual's capacity. One of the instruments used most often for evaluating coping skills is the Athletic Coping Skills Inventory-28 (ACSI-28). Objective: This study aimed to validate the Brazilian version of the Athletic Coping Skills Inventory-28 (ACSI-28). The ACSI-28 is a multidimensional inventory developed to evaluate the different methods used by athletes to cope with sports pressure. Methods: The sample comprised 667 Brazilian athletes: male $(n=467 ; 70 \%)$; female $(n=200 ; 30 \%)$ with mean age $25 \pm 5$ years and eight $( \pm 5)$ years of experience in individual sports $(n=182 ; 27.3 \%)$ or team sports $(n=485 ; 72.7 \%)$. Results: For construct validity, the relational structure of the items that comprise the original version of ACSI- 28 was analyzed using EFA. The Kaiser-Meyer-Olkin measure $(K M O=.83)$ and the Bartlett sphericity test $(p<.0001)$ indicated adequate adjustment of the data to the factorial analyses. The reliability of the instrument was assessed by measuring internal consistency and by the stability of the measurement (test-retest). Conclusion: The Brazilian version of Athletic Coping Skills Inventory-28 was preliminarily considered valid. Level of Evidence III; Retrospective comparative study.
\end{abstract}

Keywords: Psychology, sports; Validation studies; Athletic performance.

\section{RESUMO}

Introdução: Coping édefinido como um processo baseado no esforço motor, comportamental e cognitivo para lidar com as demandas psicofísicas que excedem a capacidade de um indivíduo. Um dos instrumentos mais utilizados para avaliar as habilidades de coping éo Athletic Coping Skills Inventory-28 (ACSI-28). Objetivo: Este estudo teve como objetivo validar a versão brasileira do Athletic Coping Skills Inventory-28 (ACSI-28). O ACSI-28 é um inventário multidimensional desenvolvido para avaliar os diferentes métodos utilizados pelos atletas para lidar com as pressões do esporte. Métodos: A amostra incluiu 667 atletas brasileiros: sexo masculino ( $n=467 ; 70 \%)$; sexo feminino $(n=200 ; 30 \%)$ com média de idade de $25 \pm 5$ anos e oito anos ( \pm 5 ) de experiência em esportes individuais ( $n=182 ; 27,3 \%)$ ou coletivos $(n=485 ; 72,7 \%)$. Resultados: Para a validade da construção, a estrutura relacional dos itens que compõem a versão original do ACSI-28 foi analisada usando o EFA. A medida Kaiser-Meyer-Olkin $(K M O=0,83)$ e o teste de esfericidade de Bartlett $(p<0,0001)$ indicaram ajuste adequado dos dados das análises fatoriais. A confiabilidade do instrumento foi avaliada medindo-se a consistência interna e pela estabilidade da medida (teste-reteste). Conclusões: A versão brasileira do Athletic Coping Skills Inventory-28 foi preliminarmente considerada válida. Nível de Evidência Ill; Estudo retrospectivo comparativo.

Descritores: Psicologia do esporte; Estudos de validação; Desempenho atlético.

\section{RESUMEN}

Introducción: Coping se define como un proceso basado en el esfuerzo motor, comportamental y cognitivo para hacer frente a las demandas psicofísicas que superan la capacidad de un individuo. Uno de los instrumentos más utilizados para evaluar las habilidades de coping es el Athletic Coping Skills Inventory-28 (ACSI-28). Objetivo: Este estudio tuvo como objetivo validar la versión brasileña del Athletic Coping Skills Inventory-28 (ACSI-28). El ACSI-28 es un inventario multidimensional desarrollado para evaluar los diferentes métodos utilizados por los atletas para lidiar con las presiones del deporte. Métodos: La muestra incluyó 667 atletas brasileños: sexo masculino ( $n=467$; 70\%); sexo femenino ( $n=200 ; 30 \%)$ con edad promedio de $25 \pm 5$ años y ocho $( \pm 5)$ años de experiencia en deportes individuales $(n=182 ; 27,3 \%)$ o en equipo ( $n=485 ; 72,7 \%)$. Resultados: Para la validez de la construcción, la estructura relacional de los elementos que componen la versión original del ACSI-28 fue analizada usando el EFA. La medida Kaiser-Meyer-Olkin (KMO =0,83) y la prueba de esfericidad de Bartlett $(p<0,0001)$ indicaron un ajuste adecuado de los datos a los análisis factoriales. La confiabilidad del instrumento fue evaluada midiendo la consistencia interna y la estabilidad de la medida (prueba-reprueba). Conclusiones: La versión brasileña del Athletic Coping Skills Inventory-28 fue preliminarmente considerada válida. Nivel de Evidencia III; Estudio retrospectivo comparativo.

Descriptores: Psicología del deporte; Estudios de validación; Rendimiento atlético. 


\section{INTRODUTION}

Coping is defined as a process based on motor, behavioral, and cognitive effort that is constantly being changed to deal with the psychophysical demands that exceed an individual's capacity. It is a dynamic, conscious process, during which the individual evaluates the situation as stressful, trying to utilize his resources to control, reduce, or equalize the demands of activity, requires systematic learning and training. ${ }^{1-5}$

Coping strategies have been widely used in a sporting context. Gould et al. ${ }^{6}$ analyzed the coping strategies used by medalist Olympic wrestlers, found that the medalists had more systematic and automated strategies learned. Thus, the importance of coping skills for successful sports.

Most studies that look at coping strategies utilize questionnaires. ${ }^{1}$ One of the most used for evaluating coping skills is the Athletic Coping Skills Inventory-28 (ACSI-28), a multidimensional inventory developed for evaluating the different strategies used by the athletes to deal with sports stress. ${ }^{7,8}$ It consists of 28 items, four items for each one of seven factors (coping with adversity; peaking under pressure; goal setting/ preparation; confidence/motivation; concentration; freedom from worry; and coachability).

The ACSI-28 has been utilized in studies with athletes of different modalities, ${ }^{9}$ correlation with psychological abilities, ${ }^{2,10}$ predicting expertise, ${ }^{11-14}$ injuries, ${ }^{15,16}$ eating disorders, ${ }^{17}$ and validation studies for other languages. ${ }^{3,18}$

The sports psychology in Brazil needs methods and instruments that may assist in interventions and research in sports science. Nevertheless, for use in another language and cultural reality some procedures are necessary. Thus, the first objective of the present study was to adapt the instrument in the context of Brazilian sports. The second aim was to test the validity, reliability, temporal stability and construct validity of the Athletic Coping Skills Inventory-28.

\section{METHODS}

The total sample was 667 Brazilian athletes: 70\% male ( $n=467)$, mean age: $25 \pm 5$ years, eight ( \pm five) years of practicing their sport, being $72.7 \%$ in team sports $(n=485)$.

The translation procedure and cultural adaptation of the instrument: Starting the ACSI-28 validation according to the protocol proposed by Beaton et al. ${ }^{19}$ The translation of the scale into Portuguese was done through the parallel back translation. An English teacher with sports experience translated the items of the scale. Then, a professor and a master's student in sport psychology (separately) adapted the translation in a Brazilian context. The translated version was submitted for reverse translation by a bilingual researcher experienced in sport psychology in order for it to be compared with the original scale. No discrepancies between Portuguese version and the original were observed. After, the scale was applied in a sample of 20 athletes with a mean of eight years' international sports experience. They could test comprehension of the items on the scale and make suggestions. Based on this sample, some adjustments were made, thereby producing a final version of the Portuguese ACSI-28.

Each one of the seven subscales is composed of four items scored on a Likert scale $(0=$ almost never, $1=$ sometimes, $2=$ frequently, $3=$ almost always) with 12 points. The sum of all these subscales is referred to as Personal Coping Resources (varying from 0 to 84 points). The dimensions of the ACSI-28 were defined as follows: Coping With Adversity (e.g.: I maintain emotional control no matter how things are going for me), Peaking Under Pressure (e.g.: I make fewer mistakes when the pressure's on because I concentrate better), Goal Setting/Mental Preparation (e.g.: I set my own performance goals for each practice), concentration (e.g.: When I am playing sports, I can focus my attention and block out distractions), Freedom From Worry (e.g.: I worry quite a bit about what others think about my performance), Confidence and Achievement Motivation (e.g.: I feel confident that I will play well), Coachability (e.g.: When a coach or manager criticizes me, I become upset rather than help).

The study was approved by the Ethics Committee of Human Research (CEP-UFJF: 223/2008). All athletes were informed about all procedures and signed the terms of assent form.

\section{Data analysis}

The sample was divided into two subgroups stratified by gender and age in order to maintain the proportionality. In one subgroup $(n=333)$ the relational structure of the items that compose the original ACSI-28 version was analyzed through Exploratory Factor Analysis (EFA). The adjusted assumptions of the data for this type of analysis were calculated by Kaiser-Meyer-Olkin (KMO) tests and the sphericity of Bartlett test. Methods of the main components for extracting the factors were utilized, considering only those that presented eigenvalues superior to one (1.0) and factorial load over 0.50 , followed by a Varimax rotation aiming for maximization of the factorial load independence between the factors. The reliability of the instrument was calculated through the internal consistency (alpha coefficients) and the stability of the measurement (test-retest method, intra-class correlation coefficient in a sample with 46 individuals with a week between measurements). In a second subgroup ( $n=334$ ) Confirmatory Factor Analysis (CFA) was used with an asymptotic distribution free method (ADF) to identify corresponding validation indicators using EFA. The adjusted assumptions of the data were evaluated using a Chi-square test with degrees of freedom $\left(\mathrm{X}^{2} / \mathrm{dl}\right)$, Comparative Fit Index (CFI), the Tucker-Lewis Index (TLI), the root mean square residual (RMSR) and standardized root mean square residual (SRMR). In this case, it was assumed that $\mathrm{X} 2 / \mathrm{gl}<3, \mathrm{CFI}, \mathrm{TLI} \geq 0.9$ and values $\leq 0.08$ for RMSR and SRMSR suggested a goodness-of-fit model. Additionally, we analyzed an adjusted model for the gender of the athletes, their age (e.g. young), and different levels of ability (e.g. professional), given the differences between Chi-square $\left(\Delta x^{2}\right)$ and degrees of freedom $(\Delta g l)$. The data was analyzed using the Statistical Package for the Social Sciences (SPSS) 20.0 and STATA 13.0. The significance level adopted was $p \leq .05$.

\section{RESULTS}

The KMO (0.80) and the Bartlett sphericity tests $(p<0.0001)$ indicated adequate adjustment of the data to the factorial analysis. They presented the same reliability level expected from the data when the factorial analysis method is employed with success. Table 1 presents the factorial loads of each item in the seven factors extracted ("Lidar com Adversidades", "Melhor Desempenho Sob Pressão", "Metas/Preparação Mental", "Concentração", "Livre de Preocupação", "Confiança/Motivação", "Treinabilidade") as well as the communality of each item. Loads superior to 0.40 and communalities at 0.50 are desirable..$^{20}$

Using the eigenvalue criterion superior to 1.0 and the scree-plot graphic method, the EFA by the main components method, after the Varimax rotation, identified seven latent factors in the relational structure of the items that compose the analyzed questionnaire. Such factors, accounted for $54.1 \%$ of the total variation of the data and presented, nearly the same items proposed by the original instrument. The covariance matrix of the scores of the factors presented values equal to zero, confirming independence among the factors.

The first factor, "Lidar com Adversidades" presented loads on the items $5,17,21$ and 24 equal to $.42, .50,65, .71$, respectively, being responsible for $8.6 \%$ of the total variance, related to the capacity to perform well under pressure, equal the original version. The second factor presented elevated factorial loads for the items 6, 18, 22 and 28, being denominated "Melhor Desempenho Sob Pressão", responsible for $19.5 \%$ of the 
Table 1. Factorial Loads for each question of the seven factors.

\begin{tabular}{|c|c|c|c|c|c|c|c|c|}
\hline \multirow{2}{*}{ Item } & \multicolumn{7}{|c|}{ Factors } & \multirow{2}{*}{ Communalities } \\
\hline & 1 & 2 & 3 & 4 & 5 & 6 & 7 & \\
\hline 24 & .71 & & & & & & & .60 \\
\hline 21 & .65 & & & & & & & .51 \\
\hline 17 & .50 & & & & & & & .37 \\
\hline 5 & .42 & & & & & & & .30 \\
\hline 18 & & .77 & & & & & & .69 \\
\hline 22 & & .73 & & & & & & .64 \\
\hline 6 & & .66 & & & & & & .56 \\
\hline 28 & & .63 & & & & & & .51 \\
\hline 8 & & & .72 & & & & & .56 \\
\hline 1 & & & .69 & & & & & .53 \\
\hline 13 & & & .66 & & & & & .55 \\
\hline 20 & & & .61 & & & & & .50 \\
\hline 16 & & & & -.08 & & & & .47 \\
\hline 25 & & & & .05 & & & & .44 \\
\hline 11 & & & & -.03 & & & & .38 \\
\hline 4 & & & & -.01 & & & & .05 \\
\hline 23 & & & & & .71 & & & .62 \\
\hline 7 & & & & & .71 & & & .50 \\
\hline 12 & & & & & .65 & & & .62 \\
\hline 19 & & & & & .65 & & & .57 \\
\hline 2 & & & & & & .74 & & .66 \\
\hline 9 & & & & & & .56 & & .55 \\
\hline 14 & & & & & & .28 & & .30 \\
\hline 26 & & & & & & .22 & & .56 \\
\hline 15 & & & & & & & .72 & .56 \\
\hline 27 & & & & & & & .63 & .49 \\
\hline 10 & & & & 5 & & & -.08 & .80 \\
\hline 3 & & & & & & & -.05 & .81 \\
\hline
\end{tabular}

total variance (loads ranged from .63 to .77). The third factor, (7.2\% of variance), was composed of the items 1, 8, 13 and 20, was denominated "Metas/Preparação Mental", as per the original version. The original fourth factor, namely "Concentração", comprised items 4, 11, 16, and 25 that presented ambiguous loads. The fifth factor was composed of items 7, 12, 19, 23 and presented $4.7 \%$ of variance. As proposed by the original version, the score of these items must be inverted to calculate the factor and denominated "Livre de Preocupação". The sixth factor corresponds to the items related to motivation and confidence $(2,9,14$ and 26), being, defined as "Confiança/Motivação", with $4 \%$ of variance. The seventh factor $(3,10,15$ and 27), is defined as "Treinabilidade". The variance of this factor was $4.4 \%$.

Thus, in this EFA, three factors presented problems (insufficient or ambiguous loading): "Concentração" (items 04, 11, 16 and 25), Confiança e Motivação (items 14 and 26) and "Treinabilidade" (items 3 and 10).

The internal consistency of the Brazilian version of the ACSI-28 is shown in Table 2. The stability of the instrument was evaluated through the test-retest method, with one week between the measures. Both coefficients vary between 0 and $1 .{ }^{20}$ The values found are similar to the ones reported in the validation of the original instrument.

The ACSI-28 in the Brazilian version (ACSI-28BR) is a self-administered instrument, composed of 28 questions that comprise seven coping skills, calculated from the mean of the responses of the items that constitute them. However, in the factorial validation process of the Brazilian version of the ACSI-28, the factors "Concentração" and "Treinabilidade" did not present a sufficient a to score in the composition of the scale.

Table 3 presents the correlation between the scales of the ACSI-28BR. Although the majority showed statistical significance, the correlations were moderate, indicating that the scales are independent psychological constructs. ${ }^{3,8}$

In another subgroup $(n=334)$ we conducted Confirmatory Factor Analyses (CFA). After the first step, with all seven factors and 28 items,
Table 2. Scales Composition, $\mathrm{M} \pm \mathrm{SD}$ and Coefficient of Internal Consistency of the ACSI-28 Brazilian Version.

\begin{tabular}{|c|c|c|c|}
\hline Subscale & Items & $M \pm S D$ & $\begin{array}{c}a \\
(n=333)\end{array}$ \\
\hline \multirow{4}{*}{ Coping with Adversity } & 5 & \multirow{4}{*}{1.83} & \multirow{4}{*}{.60} \\
\hline & 17 & & \\
\hline & 21 & & \\
\hline & 24 & & \\
\hline \multirow{4}{*}{ Peaking under Pressure } & 6 & \multirow{4}{*}{1.96} & \multirow{4}{*}{.76} \\
\hline & 18 & & \\
\hline & 22 & & \\
\hline & 28 & & \\
\hline \multirow{4}{*}{$\begin{array}{l}\text { Goal Setting/Mental } \\
\text { Preparation }\end{array}$} & 1 & \multirow{4}{*}{1.99} & \multirow{4}{*}{.69} \\
\hline & 8 & & \\
\hline & 13 & & \\
\hline & 20 & & \\
\hline \multirow{4}{*}{ Concentration } & 4 & \multirow{4}{*}{1.93} & \multirow{4}{*}{.43} \\
\hline & 11 & & \\
\hline & 16 & & \\
\hline & 25 & & \\
\hline \multirow{4}{*}{ Freedom from Worry } & $7^{*}$ & \multirow{4}{*}{1.57} & \multirow{4}{*}{.63} \\
\hline & $12^{*}$ & & \\
\hline & $19 *$ & & \\
\hline & $23^{*}$ & & \\
\hline \multirow{4}{*}{$\begin{array}{c}\text { Confidence and } \\
\text { Achievement Motivation }\end{array}$} & 2 & \multirow{4}{*}{2.29} & \multirow{4}{*}{.56} \\
\hline & 9 & & \\
\hline & 14 & & \\
\hline & 26 & & \\
\hline \multirow{4}{*}{ Coachability } & $3^{*}$ & \multirow{4}{*}{1.66} & \multirow{4}{*}{.34} \\
\hline & $10^{*}$ & & \\
\hline & 15 & & \\
\hline & 27 & & \\
\hline Personal Coping Resources & All items & 1.89 & .81 \\
\hline
\end{tabular}
* score inverted.

Table 3. Correlation Between the Dimensions of the ACSI-28 Brazilian Version.

\begin{tabular}{c|c|c|c|c|c|c|c|c}
\hline Subscales & I & II & III & IV & V & VI & VII & VIII \\
\hline I- Coping with Adversity & & & & & & & & \\
\hline II - Peaking under Pressure & $.38^{* *}$ & & & & & & & \\
\hline $\begin{array}{c}\text { III -Goal Setting/Mental } \\
\text { Preparation }\end{array}$ & $.34^{* *}$ & $.37^{* *}$ & & & & & & \\
\hline IV- Concentration & $.54^{* *}$ & $.46^{* *}$ & $.37^{* *}$. & & & & & \\
\hline V- Freedom from Worry & -.03 & .04 & $.14^{*}$ & .01 & & & & \\
\hline VI - Confidence/Achievement & $.36^{* *}$ & $.43^{* *}$ & $.47^{*}$ & $.41^{* *}$ & .03 & & & \\
Motivation & $.15^{* *}$ & $.22^{* *}$ & $.24^{*}$ & $.16^{* *}$ & $.17^{*}$ & $.22^{* *}$ & & \\
\hline VII - Coachability & $.62^{* *}$ & $.71^{* *}$ & $.69^{*}$ &. $.65^{* *}$ & $.33^{* *}$ &. $.64^{* *}$ & $.47^{* *}$ & \\
\hline VIII - Personal Coping Resources
\end{tabular}
${ }^{*} p<.05 ;{ }^{* *} p<.01$.

the model was concave and the computed gradient and Hessian gave a poor direction for stepping. Therefore, we removed the factors with low factorial load. First, the factor removed was "Concentração". The model remained concave. Second, we removed "Treinabilidade". However, the model with "Lidar com Adversidades", "Melhor Desempenho Sob Pressão","Metas/Preparação Mental," "Livre de Preocupação" and "Confiança/ Motivação" did not have an acceptable fit $\left(X^{2}(160)=596.32 ; X^{2} / d f=\right.$ 3.72; CFI = 0.805; TLI = 0.769; RMSEA = 0.099 (I.C. 0.090-0.107); SRMR = 0.145). Therefore, we performed an adjustment through indices based on covariance of error of the items. The better model was $X^{2}(148)=$ 336.776; $\mathrm{X}^{2} / \mathrm{df}=2.27 ; \mathrm{CFI}=0.916 ; \mathrm{TLI}=0.892 ; \mathrm{RMSEA}=0.067$ (I.C. 0.058$0.077) ; S R M R=0.114$, represented in Figure 1.

Finally, we calculated the indicators related to factorial invariance tests between different indices associated with sex and age. However, there is collinearity in both models that the command did not otherwise identify. 


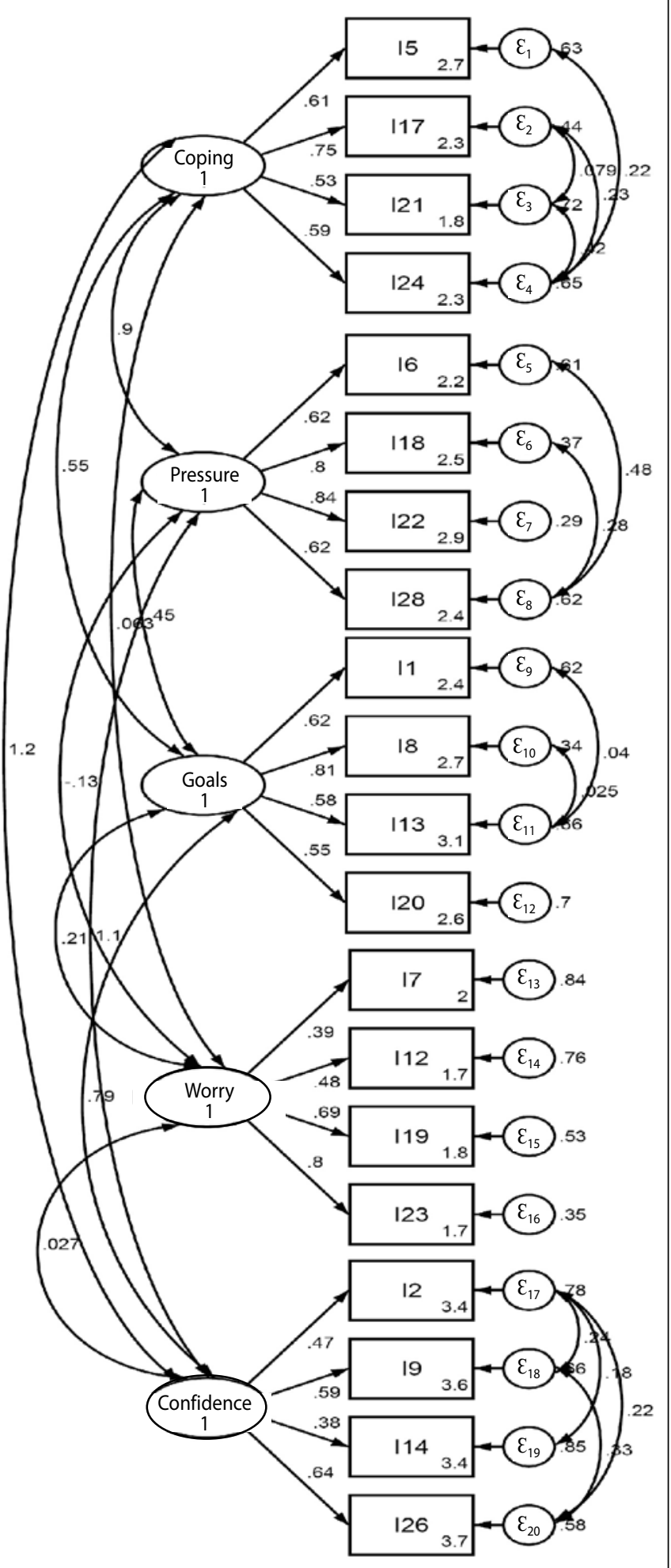

Figure 1. Factorial Structure of the ACSI-28 Brazilian Version.

\section{DISCUSSION}

This study carried out the validation of ACSI-28 for Brazilian athletes, an instrument to evaluating the coping skills. After the parallel back translation that resulted in a Brazilian version of ACSI-28, the statistical tests presented support for the translated version, with validation using EFA, reliability (a) and time stability (test-retest) of the now called ACSI-28BR.

From the EFA, similarities could be observed between the current study and the original in four of the seven dimensions that make up the ACSI-28. The EFA of the items of the scale indicated that the items
5, 17, 21, and 24 belonged to the same factor, "Lidar com Adversidades", corresponding with Coping With Adversity (Smith et al. ${ }^{8}$ ). Similar results could be seen in the factor "Melhor Desempenho Sob Pressão", in which the items 6, 1822 and 28 were the same as the original scale. The third factor, "Metas/Preparação Mental", also corresponded with the original items on the scale (1, 8, 13, and 20). The fifth factor, "Livre de Preocupação", as in the original version, was made up of the items 7, 12, 19, and 23. The sixth, "Confiança/Motivação", showed that 2 and 9 had a high load and 14 and 26, a small load. For the fourth, "Concentração", and seventh, "Treinabilidade", items were removed, since they presented some poor or ambiguous factors.

One of the seven factors, besides the total scale, presented alpha values higher than 0.70 . However, considering that each dimension was made up of three or four items, lower values were expected in the internal consistency, such as the original, ${ }^{8}$ Greek, ${ }^{3}$ and Spanish version. ${ }^{18}$ Overall, the internal consistency values found were similar to the original study, except for the scales that had poor items: "Treinabilidade" and "Concentração". The current study also identified good temporal stability through the test-retest method, presenting higher values than the validation study of the original version. ${ }^{8}$ These outcomes were expected because the coping strategies indicated by the ACSI- 28 are relatively stable. ${ }^{21}$ The factors have been shown as significantly correlated, since the correlation factors presented were low., 3

In CFA, the factorial structure analyzed was a five-factor model. For a good adjustment, we used modification indices. Only SRMR did not have a good value.

In Brazilian Portuguese, there is a lack of translated instruments able to be used to measure such ability. Hence, the realization of studies with the ACSI-28 enables the utilization of such an instrument to evaluate the coping in Brazilian athletes.

The analysis of the collected data from the application of the Brazilian version of the ACSI-28 revealed divergent outcomes when compared to the validation of the original instrument ${ }^{8}$, due to the exclusion of three factors (Training, Concentration, and Confidence/ Motivation) of the seven originally proposed factors. The ACSI-28BR was shown as valid regarding clarity, and presented adequate reliability and validity evidenced by the coefficients and factorial loads found.

Thus, the strength of the present study is the confirmatory factorial analysis and exploratory factorial analysis from the same database. However, because of the removal of three items in different subscales, it makes the cross-cultural aspects less subjective utilizing the factors: "Treinabilidade", "Concentração", and "Confiança/Motivação" of the ACSI-28BR. Another limitation was the application of instruments to sports that are little known in Brazil (Hapkido, Jiu Jitsu, and Muay Thai). However, as the objective of the study was to validate the ACSI-28, we believe that expanding the number of modalities is important for the future use of the instrument.

In spite of the limitations presented, this study met the necessary validation criteria. Furthermore, the total validation of a psychometric instrument takes time, and a large sample, a variety of statistical tests and cultural adaptation procedures would be required. As indicated in previous research, the ACSI-28 (and the ACSI-28BR) measures psychological coping abilities, or coping strategies. ${ }^{4}$

Any attempt of validation of an instrument is surrounded by difficulties. Especially when considering an embracing and multifaceted phenomenon such as coping.' In the same way, it requires its own validation methods in order to be analyzed in practice, because this is one of the main gaps in sport sociology. Brazil is still far from this idea of developing its own instruments for the sports that contribute to the evolution of Brazilian sport.22 
For a success performance, the development of psychological capabilities is as fundamental as the physical, technical, and tactical ones. Our ambition with the validation of the ACSI-28BR is not to select or discover talents. ${ }^{3,8}$ Considering the possibilities of committing interpretation errors and athletes giving socially desirable responses to the instrument, the ACSI-28BR must not be used for this purpose. Additionally, to maintain the original structure, we recommend the application of the 28 items on the scale, but with caution in the scales with poor factorial load.

\section{CONCLUSION}

The Brazilian version of Athletic Coping Skills Inventory-28 was considered valid. However, "Concentração" and "Treinabilidade" did not show good factor loads and need to be analyzed with caution in future studies. Furthermore, there is a potential to look at correlations between the psychological abilities and identify which are the most crucial ones for success.

All authors declare no potential conflict of interest related to this article.

AUTHORS' CONTRIBUTIONS: Each author made significant individual contributions to this manuscript. RM (0000-0002-1127-8513)*: responsible for the conception of the idea, discussion of the results, critical writing of the intellectual content, revision and approval of the final version; DRC (0000-0002-6055-0667)*: writing, conducting data collection, analysis and interpretation of results, discussion of results and approval of the version; MGBF (0000-0003-1219-8379)* writing, discussion of results and approval of the final version; MVMJ (0000-0001-8329-9383)*: accomplishment of data collection, writing and approval of the final version; AA (0000-0002-6640-9314)* discussion of the results, writing, review and approval of the final version. All authors contributed to the intellectual concept of the study. ${ }^{*} \mathrm{ORCID}$ (Open Researcher and Contributor ID).

\section{REFERENCES}

1. Nicholls AR, Polman RC. Coping in sport: a systematic review. J Sports Sci. 2007;25(1):11-31.

2. Cresswell S, Hodge K. Coping skills: role of trait sport confidence and trait anxiety. Percept Mot Skills. 2004;98(2):433-8

3. Goudas M, Theodorakis Y, Karamousalidis G. Psychological skills in basketball: preliminary study for development of a Greek form of the Athletic Coping Skills Inventory-28. Percept Mot Skills. 1998;86(1):59-65.

4. Lazarus R, Folkman S. Stress, appraisal and coping. New York: Springer; 1984.

5. Tobar BU. Evaluación de la efectividad del entrenamiento de estrategias de afrontamiento en el nivel de ansiedad precompetitiva en tenimesistas. Rev Psicol Deporte. 2014;23(1):64-74.

6. Gould D, Eklund RC, Jackson SA. Coping strategies used by U.S. Olympic wrestlers. Res Q Exerc Sport. 1993;64(1):83-94

7. Smith RE, Christensen DS. Psychological skills as predictors of performance and survival in professional baseball. J Sport Exerc Psychol. 1995;17(4):399-415

8. Smith RE, Schutz RW, Smoll FL, Ptacek JT. Development and validation of a multidimensional measure of sport-specific psychological skills: the Athletic Coping Skills Inventory-28. J Sport Exerc Psychol. 1995;17(4):379-98.

9. Bebetsos E, Antoniou P. Psychological skills of Greek badminton athletes. Percept Mot Skills. 2003;97(3 Pt2):1289-96.

10. Omar-Fauzee MS, Wan Daud WR, Abdullah R, Rashid SA. The Effectiveness of imagery and coping strategies in sport. European Journal of Social Sciences. 2009;9(1):97-108.

11. Coetzee B, Grobbelaar HW, Gird CC. Sport psychological skills that distinguish successful from less successful soccer teams. J Hum Movem Stud. 2006;51:383-401.
12. Cox RH, Shannon JK, McGuire RT, McBride A. Predicting subjective athletic performance from psychological skills after controlling for sex and sport. J Sport Behav. 2010;33(2):129-45.

13. Van Der Heever Z, Grobbellar HW, Potgieter JC. Sport psychological skills and netball performance. Hum Movem Stud. 2007:52:109-24.

14. Weissensteiner JR, Abernethy B, Farrow D, Gross J. Distinguishing psychological characteristics of expert cricket batsmen. J Sci Med Sport. 2012;15(1):74-9.

15. Johnson U, Ivarsson A. Psychological predictors of sport injuries among junior soccer players. Scand J Med Sci Sports. 2011;21(1):129-36.

16. Maddison R, Prapavessis H. A psychological approach to the prediction and prevention of athletic injury J Sport Exerc Psychol. 2005;27(3):289-310.

17. Estanol E, Shepherd C, MacDonald T. Mental skills as protective attributes against eating disorder risk in dancers. J Appl Sport Psychol. 2013;25(2):209-22.

18. Sanz JL, Pérez LM, Coll VG, Smith RE. Development and validation of a Spanish version of the Athletic Coping Skills Inventory, ACSI-28. Psicothema. 2011;23(3):495-502.

19. Beaton D, Bombardier C, Guillemin F, Ferraz MB. Recommendations for the cross-cultural adaptation of health status measures. New York: American Academy of Orthopedic Surgeons; 2002.

20. Hair JF Jr, Anderson RE, Tatham RL, BlackWC. Análise multivariada de dados. 5.ed. Porto Alegre: Bookman; 2005.

21. Crocker PR, Kowalski KC, Graham TR. Measurement of coping strategies in sport. In: Duda JL. (Ed.). Advances in sport and exercise psychology measurement. Morgantown, WV: Fitness Information Technology; 1998

22. Gomez SS, Coimbra DR, Guillén Garcia F, Miranda R, Bara Filho M. Análise da produção científica em psicologia do esporte no Brasil e no exterior. Revista Iberoamericana de Psicología del Ejercicio y el Deporte. 2007;2(1):25-40 